\title{
QUEEN'S
UNIVERSITY
BELFAST
}

\section{Institutions and the Industrial Relations Tradition}

Cullinane, N. (2014). Institutions and the Industrial Relations Tradition. In A. Wilkinson, G. Wood, \& R. Deeg (Eds.), The Oxford Handbook of Employment Relations: Comparative Employment Systems (pp. 222-240). Oxford University Press. http://ukcatalogue.oup.com/product/9780199695096.do

\section{Published in:}

The Oxford Handbook of Employment Relations: Comparative Employment Systems

\section{Document Version:}

Publisher's PDF, also known as Version of record

Queen's University Belfast - Research Portal:

Link to publication record in Queen's University Belfast Research Portal

Publisher rights

(c) 2014 Oxford University Press

\section{General rights}

Copyright for the publications made accessible via the Queen's University Belfast Research Portal is retained by the author(s) and / or other copyright owners and it is a condition of accessing these publications that users recognise and abide by the legal requirements associated with these rights.

Take down policy

The Research Portal is Queen's institutional repository that provides access to Queen's research output. Every effort has been made to ensure that content in the Research Portal does not infringe any person's rights, or applicable UK laws. If you discover content in the Research Portal that you believe breaches copyright or violates any law, please contact openaccess@qub.ac.uk. 


\title{
INSTITUTIONS AND THE INDUSTRIAL RELATIONS TRADITION
}

\author{
NIALL CULLINANE
}

\section{INTRODUCTION}

Institutions have remained central to industrial relations (IR) analysis in terms of understanding the behaviour of IR actors and the outcomes of IR processes. Within the IR tradition, the most influential accounts on institutional effects have dovetailed with a broadly functionalist sociology. Historically, this inclination, in turn, has tended to generate an auto-critique broadly underpinned by various 'conflict' sociological theories. The purpose of this chapter is to consider the functionalist legacy in institutional analysis and the underlying, if not always self-consciously realized, sociological borrowings. The chapter considers the associated critiques of such postures and subsequent attempts to build upon and refine such analysis.

The argument of the chapter is as follows: it will open with a brief review of the early institutional-pluralist schema of IR offered by the US 'Berkeley-Harvard' tradition. A number of complementary, sociological parallels are found: chiefly the structural-functionalism of Talcott Parsons, itself leaning heavily on a particular reading of Durkheim. Yet for further sociological development of IR institutions, the chapter argues, it is not to the United States that one must look, where the field of IR was subsequently subsumed by neo-classical labour economics, but to Britain. In Britain, while a latent functionalism was often apparent in the work of Oxford scholars, explicit sociological anchoring in Durkheim was used to explain the inflationary disorder' that spawned the important Donovan Commission (Fox and Flanders 1969). As this tradition was seriously challenged by Marxist sociology and labour process analysis in subsequent years (Hyman 1975; Nichols and Beynon 1977), the 
Durkheimian sociology of IR institutions was in turn reconstructed and elaborated by radical-institutionalists to explain 'disorder' as a product of liberal market societies (Goldthorpe 1969; Fox 1974; Gilbert 1986). While such sociological underpinnings eroded as the full effects of the 'monetarist counter-revolution' were felt throughout the 1980 os and 1990s, a space for such thinking re-emerged in subsequent developments around Durkheimian neo-pluralist approaches to the employment relationship (Ackers 2002, 2012) and the varieties of capitalism (VOC) literature in particular (Frege and Kelly 2004). The VOC literature has been particularly influential in the IR world and the various linkages between the two, and their intertwining sociological aspects, are discussed.

\section{SOCIOLOGY AND THE Institutional-Pluralist Tradition}

Institutions have long been central to IR analysis. Different regulatory institutions were recognized by the earliest pioneers of the field like Webb and Webb (1920), who notably distinguished between legal enactment and collective bargaining, and Commons (1950) and Perlman (1928), who attached primary importance to understanding the emergence of 'rules of occupancy and tenure.' Yet the first schematic attempt to trace out the centrality of institutions in IR may well derive from the 'Berkeley-Harvard' tradition in the United States. One of their chief scholars, John Dunlop (1958), treated IR as an 'analytical subsystem' of industrial society, in turn identifying three important actors within this system: workers, management, and the state. Through their interactions, these agents produced a web of substantive and procedural rules, regulating conflict and promoting social order. Complementing such rules were influences of a sociological nature: a broadly 'common ideology' about 'acceptable behaviour' within the system. The historical emergence of this system is portrayed in Kerr et al. (1973), on foot of a sociological theory around changing social structures in industrialized societies. This thesis argued that while worker militancy and social conflict peaked during the early course of industrialization, it progressively dissipated in intensity thereafter as organized labour habituated itself to industrialism and employers grew to accept the legitimacy of collective bargaining. Such development permitted the emergence of institutions for conflict containment, which, in turn, cultivated an ethic of compromise and piecemeal advancement. The latter held sway due to a widespread acceptance of the material wealth and degree of social liberty afforded by industrial society. A further 'logic' of this industrialism led to the formation of social structures punctuated by various social gradations. Thus 'class conflict' associated with early industrialism gave way to a conflict between pluralistic 'interest groups'. The crisis of industrialization was resolved, the working class were integrated into its structures, and all subsequent labour problems were principally technocratic matters or perhaps 
generated by recalcitrant minorities 'with a conflicting, exclusive ideological orientation' (Kerr 1964: 15). This was held to be a trend upon which all industrialized societies institutionally converged.

On review, the sociological assumptions behind this institutionalism appear closely bound up in Cold War liberalism. It was closely affiliated with the first wave of pluralist theorizing in the field of US political science (Dahl 1958), but also, more importantly, functionalist sociology (cf. Poole 1981). Central to functionalism was an interpretation of society as a structure with interrelated, constituent elements like norms, customs, traditions, and institutions. Each of these performed a particular role or 'function': the different parts acting as 'organs' that worked towards the proper functioning of the body (society) as a whole (Giddens 1984). Talcott Parsons is typically identified as the chief architect of this system in post-war sociology and indeed Dunlop (1958: 28-32), in constructing his IR sub-system, explicitly borrowed from his sociology. Parsons's (1951: 24) analysis starts from the problem of order in society: conflict was inevitable where a 'plurality of individual actors' pursued their ends in circumstances of scarcity. Since disorder was an omnipresent probability, Parsons sought to account for how order was actually obtained in the absence of obvious manifest conflict. This led him to emphasize the durable properties of societies which enabled stable maintenance and reproduction without being torn asunder. In this regard, Parsons concluded that social and cultural norms had a crucial role to play in reconciling the ends of individual actors and integrating them: what Lockwood (1993) elsewhere terms 'normative functionalism. This was not sociological idealism, however, as norms interfaced with a distinct social structure or system of 'rule institutionalization'. As norms were deemed to be largely internalized by social actors, except for occasional 'deviants' (Parsons 1951: 250), the tendency was consequently towards a self-equilibrating system. Some modicum of 'social strain' was not wholly avoidable and taken as given due to the pluralistic multitude of associational structures. These latter bodies in any case impeded excessive concentrations of power.

The construction of such sociological foundations relied heavily upon a particular reading of Durkheim: indeed Parsons (1968, cited in Gouldner 1971: 163) freely admitted that his 'own inclination is to refer above all to Durkheim' in the construction of his sociology. The comparisons are, at one level, apt: Durkheim's sociology was similarly preoccupied with explaining how societies and social groups held together as structures. Parsonian interpretations of social and cultural norms echo Durkheim's (1982) external constraints of intangible 'social facts', while the aforementioned normative functionalism of industrial society is reflective of Durkheim's (1984) 'mechanical solidarity'. Yet in the American construction of the IR institutional framework Durkheim remains largely ignored, coming through only in reference to Parsons. This might be accounted for by the relatively limited sociological theorizing that characterized the field of study in the US where the parameters of the debate were between institutional and neo-classical labour economics and later social psychology (Godard 1994; Kaufman 2004). It is only when we turn to the British tradition of institutional analysis that we find Durkheimian sociology more fully elaborated. 
Yet this is perhaps curious as, in contrast to Dunlop and Kerr, the main architects of British IR institutionalism, Hugh Clegg and Allan Flanders, had relatively little contact with sociology in the early part of their careers. Indeed the preface to The System of Industrial Relations in Great Britain displays some scepticism towards sociology, at least in its crude human relations guise (Flanders and Clegg 1954: v-vi). Both Clegg and Flanders would later thaw in their attitude to the discipline, primarily through their contact with the industrial sociologist Alan Fox and the Warwick Industrial Relations Research Unit, where a 'sociological wing' of IR emerged in the 1970 (Ackers 2011). Although sociological functionalism is not explicitly self-evident in the workings of the 'Oxford School', if we accept Fox's (1971: v) critical characterization of British institutionalists as those 'who concern themselves with what are currently defined... as "problems" which impede or threaten what they deem the orderly and "rational" working of the industrial relation system' then an underlying species of functionalism might be discerned. More pertinent is the summation offered by Martin (1999:1213), who senses a 'functionalist tradition... dominat[ing] the field historically, although usually implicitly and without the theoretical apparatus often associated with functionalism in mainstream sociological theory'. Flanders (1970: 86), as is well known, asserted that 'a system of industrial relations is a system of rules' and that the 'study of industrial relations may therefore be described as a study of job regulation'. While Hyman (1975: 11) complained such rendering made the field of IR a bedfellow of 'conservative sociology' (cf. Blyton and Turnbull 2004), Clegg (1979: 451) openly approved the 'conservative implications' of words like 'regulation' and 'system' in the IR lingua franca. Further, the type of assumptions that underwrote Kerr's thesis on industrial society occasionally found voice in the analysis of the British institutionalists even if they came to similar conclusions through very different pathways. Clegg's (1960: 29) social philosophy, for example, appeared to rotate on a belief that the 'political and industrial institutions of the stable democracies already approach the best that can be realized', while it would appear that Flanders was not averse to such Whiggish evaluations either (Kelly 2010). The social-democratic project of moderate reform was seen to have been secured by the 1945 Labour government: the role of IR, in true functionalist fashion, was to simply perfect the post-war settlement and the various institutions that supported it. This rational, piecemeal liberal reform could be achieved for example through encouraging progressive management and responsible trade unionism (Flanders 1964: 248-56).

From a theoretical viewpoint, the institutional arrangements provided for collective bargaining were deemed the central pivot upon which workplace actors' behaviour ultimately rested. The seminal contribution in this regard is probably Clegg's (1976) Trade Unionism Under Collective Bargaining. Choosing six countries, Clegg set out to demonstrate that union behaviour was a function of the state and character of collective bargaining in these countries. High union density among private sector manual workers in Sweden, for example, was accounted for by the relatively easy and widespread recognition of unions extended by the central employers' organization. In France, by contrast, 
employer resistance to collective bargaining in the private sector, coupled with union preference for political action, led to lower rates of unionization. Clegg also claimed to identify the pervasive effects of the structuring of collective bargaining institutions upon several major facets of IR outcomes like union government, the distribution of power within union structures, and different strikes rates. Thus the institution of collective bargaining was endowed with a functionalist property to shape a variety of complementary outcomes.

While this British tradition often echoed functionalist inclination in variously subtle ways, it is the open engagement with Durkheim where these tendencies become most manifest: in particular the emphasis on 'normative regulation for the maintenance of social order' (Fox and Flanders 1969: 156). It is here, in an influential paper by Fox and Flanders, that Durkheim is used to explain the roots of industrial disorder in Britain during the long boom. Trends such as a rising rate of unofficial strike action, wage drift, inflation, and low productivity were viewed as a reflection of institutional lag, inadequate grasp of the sources of disorder, and reluctance on the part of management and unions to depart from well-tried practices. As such, the understanding of the British institutionalists was that Durkheim's analysis complemented their own framework in the acknowledgement of autonomous interest groups and associated inter-group competition that marked out industrial societies. Other complementary points of analysis could also be found: Durkheim maintained that it was neither necessary nor possible for social life to be without conflict, it could therefore not be suppressed, only regulated (cf. Clegg 1975: 309 for a similar approach). Indeed much like the IR institutionalists, Durkheim could be found to hold a dual perspective on social conflict: as both an inevitable feature of social life, but as potentially disruptive of social order (Flanders 1970: 26; Fox and Flanders 1969: 158). Influenced by their own 'normative systems', interest groups in exchange with each other could collapse into a Hobbesian war of all against all, without due concern for social proportion (Fox and Flanders 1969: 156). In this regard, institutionalist analysis, as befitting a field concerned with the making and administration of rules regulating employment, emphasized 'collective bargaining' as then being the principal norm-creating institution which might keep conflict within socially tolerable bounds. This was achieved because the rules it produced were seen to be supported by a sufficiently high degree of consent among those whose interests were most affected by their application (Fox and Flanders 1969: 160). Nevertheless for various reasons, if the institutional fittings were not rightly inserted, anomie or disorder was held to result.

Confining their analysis to industry level, Fox and Flanders (1969: 176-7) identified institutional forms which could be implemented at different, but interrelated levels of industrial life. Specifically at enterprise level, normative integration was held attainable through productivity agreements and job evaluation schemes; industry-level guidelines devised by employer associations and trade unions could complement this as could inter-industry normative regulation for public bodies concerned with prices and incomes and good industrial relations. Thus, through a process of exclusively workplace 
and industry-level re-engineering, the functionalist equilibrium could be restored and the more vexed strains in the system could be smoothed out.

\section{SOCIOLOGY IN THE RADICAL-INSTITUTIONALIST TRADITION}

Problematically, the institutional pluralist project occurred in a context where the conditions of the post-war settlement was progressively unravelling as a result of rising strike action, profit squeeze, and the stagflationary crisis of the 1970 (Glyn and Sutcliffe 1972; Armstrong et al. 1984). By the start of the 1970s, civil rights unrest, growing industrial conflict, and the persistence of inequality in liberal, or social-democratic, societies appeared to suggest flaws in the conceptual schema associated with functionalist analysis and the more benign readings of 'dispersed power' provided by classical pluralism. As the consensus deteriorated, elements of Western intellectual life became increasingly radicalized. Parsons's sociology, having reached the zenith of its influence in the 1940s and 1950s, was, by the late 1960s, in decline as its place in the academy was increasingly supplanted by more 'conflict oriented' approaches (Dahrendorf 1959). The first wave of pluralist political science, associated with the likes of Dahl and others, was progressively challenged by a range of alternative theoretical traditions that presented empirical and conceptual criticisms of the pluralist case (Domhoff 1967). Institutional IR was not immune to such influences. The rise of the Marxist academy and New Leftism in British IR (Allen 1971; Hyman 1975), and its attempt to re-shift the analytical lens away from stability and order towards class and conflict, reflected this trajectory. Sociologically, Braverman (1974), and associated labour process analysis, placed its store on conflict and control which appeared more germane to a radicalized climate keen to reject frameworks that sought a dissipating social order. In the United States, the dynamic in IR was different, but the institutionalists suffered a much greater, and unremitting, marginalization. As the hollowing out of the New Deal IR system steadily continued into the 1970 S and 1980s, the institutionalist paradigm was eclipsed (Kochan et al. 1986). The strong labour economics tendency in IR began to dominate, particularly under the influence of neo-classical mathematical modelling, while the diffusing of non-unionism and human resource management (HRM) further accelerated the death-knell for Dunlop's system. This was not strictly the fate of IR institutionalism in Britain, where the challenges of the 1970 s produced an element of self-reflection and critical engagement with radical thinking (Clegg 1975, 1979). It is this dialogue within the British IR tradition that we now turn to.

Radical IR scholarship deeply distrusted the 'conservative tradition' of institutionalist IR given its emphasis upon the search for order. The institutions of IR were seen mainly as vehicles for the 'management of discontent': useful mechanisms by which the capitalist class, with the aid of incorporated union bureaucrats, or wider ideological 
socialization, assuaged conflict down easily manageable channels of containment (Herding 1972; Hyman 1975). Concern was raised too over the bounding of IR into a self-contained sub-system of institutions, shorn of any wider socio-political context. This coexisted with criticisms of an associated tendency to cast human actors, particularly in the Dunlopian formula, as unreflexive carriers of the roles allocated to them by the system's 'functional imperatives'. Further, by appearing to emphasize the formal processes of institutional rule-making, such bias was claimed to ignore the role of informal work groups and shopfloor stewards, whose militancy posed a challenge from below to official IR institutions in many countries in the 1960 s and 1970s. Analytically then, institutions appeared to play a secondary role in radical analysis, as the focus turned to consider social processes of conflict generation at the point of production.

Yet dissatisfaction with the institutionalist tradition also stemmed from an alternative sociological persuasion that was neither politically Marxist nor labour process inspired. An interesting exemplar of this tradition is the then view of the British sociologist, Alan Aldridge. Commenting on the institutionalist tradition in British IR, Aldridge noted that:

[Institutionalist IR] is an inbred literature, the child of an over-eager division of labour. Their desire to remain in touch with the industrial world and to avoid being digested by the academic has had as its darker side a narrowness of focus and lack of ambition... It would, of course, be ridiculous to dream that the student of industrial relations should be a new Renaissance Man intimately acquainted with the intricacies and profundities of every social science: investigation has to end somewhere and human abilities are finite. Nevertheless, limited capacity is not the same thing as complacent abstemiousness. (Aldridge 1976: $\mathrm{x}$ )

Aldridge in particular identified how institutionalists deployed ostensively sociological concepts like 'consent' as explanatory sources in determining the way particular institutional arrangements, like collective bargaining, worked. Yet the concept of consent, long puzzling to political philosophers and sociologists, was used in the literature of institutional IR as though its meaning was self-evident. Such inclinations, Aldridge maintained, had effectively exposed the institutionalist pluralist's 'left flank to attack [by] radicals and Marxists'. Institutionalists were urged to engage with the sociological origins of such concepts, which they could do without putting on the strait-jacket of socalled 'authoritarian orthodoxies'. Aldridge's critique was not isolated and perhaps better known arguments were volleyed by the industrial sociologists Alan Fox (1973) and John Goldthorpe $(1969,1977)$. Indeed the latter's critique is of note, arising as it does from an argument that Durkheim's sociology had not been fully appreciated by the institutionalist tradition in their argument on disorder. Goldthorpe held that the institutionalists had failed to follow Durkheim in relating the problem of anomie to wider social inequalities and the necessity of a wider egalitarian restructuring of society if normative order was to follow. Notably, there is evidence of cross-fertilization between Fox and Goldthorpe in the construction of their respective sociologies of IR (Fox 1971: vi; Goldthorpe 1975: 135). Considered alongside the later efforts of the sociologist Michael Gilbert (1986), who 
sought to build upon Fox's and Goldthorpe's analysis, one can trace a particular 'school' of IR: one that emphasizes the anomic temperament of industrial relations and the dearth of normative constraints on distributional conflict within advanced industrial societies (cf. Heery 2008: 73). These scholars sought to attach sociology to institutional analysis so as to explain the ubiquitous problems of strikes, wage drift, inflation, and productivity lag. Institutions were given their due importance, but were cast in preinstitutional, sociological roots that were seen to structure a path-dependent logic to the trajectory of national IR systems. Like the institutional-pluralists, the disorder associated with the Donovan era was similarly a concern, but it was held to be a more intractable problem requiring what today might be termed 'institutional complementarities' across the socio-economic structure for it to be minimized (Howell 2003; Coates 2005). Such complementarities could only be secured through radical restructuring.

Specifically, institutional disorder arose from an unequal division of labour in the employment relationship, the particular variety of British capitalism based on a historical tradition of laissez-faireism and associated economistic sectionalism. Thus, in his study of the consequences of the employment relationship in industrial societies, Fox (1974) advanced how the historical imposition of such roles gave rise to a 'large proportion' of the population working in 'low-discretion' work tasks (Fox 1974: 16-20). This was said to bound employees to prescribed routines and, moreover, social inequality, based on income and social status, tended to vary directly with levels of job discretion. Fox maintained that those occupying low-discretion work roles were managed on the assumption that they were undeserving of trust and could not be relied upon to voluntarily act in accordance with the values of superordinates. This created reciprocal distrust: people who felt that they were not trusted responded in turn by distrusting those deemed to distrust them. The implications of this low-trust syndrome for workplace relations were held to be as follows: low-trust perceptions engendered, or accentuated, the characteristics of economic exchange where employees traded specific services, or quanta of effort, for tightly specified material rewards (Goldthorpe et al. 1968: 189-90). Both sides relied upon distributive bargaining and pressure tactics to determine the terms of the exchange.

Although this was held to be a long-run trajectory of industrialization more generally, it was proposed that such trends could vary and be mediated by national social values and historical institutional and economic arrangements which would reduce 'low-trust' tendencies (Fox 1985a: 49; Gilbert 1986: 36). In Britain, low-trust economism was held to be exacerbated by its particular arrangement of these dynamics (Goldthorpe 1978: 2001; Fox 1985b: 191-9; Gilbert 1986: 64-6). As British industrialization had depended relatively little on government action, this translated into a cultural laissez-faireism which stressed individual rights and liberties rather than collectivist obligations and responsibilities. The values espoused by market relations, as they developed under British industrialization, demanded that contracting individuals be freed from all non-economic ties and obligations, while notions of government non-interference extended to the sphere of IR in the form of liberal-voluntarism. In the absence of any centralizing or corporatist tendencies, individual managements and employees were left to bargain over contracts 
that they entered into without, as in other countries, the government seeking to extensively regulate the terms of those contracts.

Under these circumstances British organized labour enacted the values of self-interested behaviour. Bargaining was confined to purely economic matters and British unionism revolved around groups of workers in sectional conflict with one another, warily guarding their differentials over lower paid groups or seeking to catch up with those who were just above (Fox 1974: 331; Goldthorpe 1978: 199; Gilbert 1986: 38). As existing market and social inequalities could no longer be legitimated by reference to norms of social superiority, as in pre-industrial societies, it was open to groups of employees to assert and maximize their market power to enhance their labour market standing (Gilbert 1986: 38). In the post-war context of supportive full employment and economic expansion, economistic striving was asserted to have increased in pervasiveness and intensity, as appetites were whetted by growing prosperity and a 'revolution of rising expectations' and 'increased worker pushfulness' (Goldthorpe 1978: 201). It was advanced that British workers felt no obligation to hold back on demands or aspirations that they might have as 'nothing in the culture surrounding them convinced them that there might be some higher good to which they should abrogate themselves; this was not part of the English individualist tradition' (Fox 1985b: 24). It was in this way that the 'low-trust dynamic' projected from the individual division of labour in the workplace to the society at large in the form of wage scrambles, strikes, and rising inflation (Fox 1974: 322).

While the sociological foundations for their analysis were frequently diverse, drawing upon Marxist and Weberian ideas, there was nonetheless again a strong Durkheimian element to this core argument in that its treatment of disorder in British IR closely correlates with Durkheim's own treatment of anomie (cf. Lockwood 1993). For Durkheim, anomie operated at three levels: first, anomie was derived from the loss of social cohesion engendered by the intensified division of labour in industrial societies as 'the individual hemmed in by his task becomes isolated... [and] no longer feels the idea of a common work being done by those who work side by side' (Durkheim 1984: 357). This was held to detach the individual worker from the wider community as 'the peculiar scope of his special activity... constantly links him to his own private interest whose true relation with the public interest he perceives but very vaguely' (Durkheim 1984: 357-8). Second, anomie arose from the free play of laissez-faire market forces and the disordering effects they were seen to sponsor: 'Production becomes unbridled and unregulated... From this comes the crisis which periodically disturbs economic functions' (Durkheim 1984: 366-7). Third, anomie was attributed to the tendency of market societies to cultivate 'excessive individualism' (Durkheim 1952: 217). Whereas pre-industrial societies were claimed to have provided a normative status order offering a glue of consensual values about the relative worth of different groups of people, industrialization, and the emergence of market forces, were seen to have relaxed such social bonds. The commercialization of exchange relationships, and the spread of the cash nexus, undermined previously accepted notions of obligations and responsibility. Industrialization was seen to engender an abrupt growth in wealth and 'with increased prosperity, desires 
increase' (Durkheim 1959: 242). As status began to depend more on individual achievements in market exchange and less on localized interactions, 'unrestrained' and 'excessive appetites' arose which could not be reconciled by traditional sources of authority. The absence of moral order led to 'unlimited desires' expressed behaviourally through various interest groups attempting to assert their power so as to enhance their material rewards:

Some particular class especially favoured by the crisis is no longer resigned to its former lot, and, on the other hand, the example of its great fortune arouses all sorts of jealously below and about it. (Durkheim 1952: 252-3)

All three sources of anomie were mutually reinforcing: if anomie in social life was to be curtailed, all three variants would need to be tackled (Durkheim 1959: 243-4; 1984: 37). This could be achieved through reconstituting a 'corporative reorganisation of modern society' (Durkheim 1959: 30-1). Similarly for Fox, Goldthorpe, and Gilbert the unbridled pluralism of British society was seen to frustrate macroeconomic management: the putative 'disorder' could be resolved only by moving away from pluralism towards a concerted arrangement. The labour market would need to be organized in a way to ensure social integration and involvement of workers through moving beyond a wholly contractual order and building institutions that forged a social compromise between capital and labour (Fox 1985b: 119-28; Gilbert 1978: 749-50; Goldthorpe 1984: 323-9).

\section{The Sociological Tradition in CONTEMPORARY InSTITUTIONAL ANAlysis}

As these radical sociologists suspected, a fundamental overhaul of British IR institutions towards social corporatism was unlikely, particularly in light of the emergence of Thatcherism: its associated advancement of economistic free-for-all was seen as more consonant with the British individualist tradition. Yet Thatcherite politics was regarded as likely to stoke, rather than tame, disorder: its application to British IR was expected to exacerbate traditional patterns of adversarial relations and institutional mistrust, which, in time, would inevitably be renewed by organized labour during an economic upswing (Fox 1985a: 429; Gilbert 1986: 80-9). Yet Thatcherism, and the economic and social changes it engendered, in time displaced the labour problem, marginalized trade unions, and hollowed out the voluntarist system of collective bargaining. The IR paradigm more generally, whatever its particular sociological casting, as well as associated normative traits, appeared progressively out of sync as non-unionism and individualistic human resource management took hold. Where sociology had any influence it continued to be heavily anchored, not in Durkheim's search for cohesion, but in Marxist labour process theory (Thompson 1982) and the continued study of job controls 
(Edwards and Scullion 1982; Terry and Edwards 1988). Much of this sociological tradition fell from grace, however, as Marxism suffered political and ideological setback in the late 1980s while the manufacturing economy, which held host to such investigations, was subject to neo-liberal shock therapy. To a lesser extent, and more in the field of political science than classical IR, sociological interpretations of institutions remained evident in the macro-examination of formal arrangements at national level (Schmitter 1974). As the long post-war boom faltered in the 1970 and as mass unemployment re-emerged, attention switched to the factors influencing national economic performance. There was a growth of research on corporatism and the systems of IR in Northern Europe that coordinated wage bargaining and generated relatively low inflation and low unemployment (Goldthorpe 1984). For the most part, however, sociology in IR, as Wood (2000) observed, gave way to economics. Increasingly this took the form, as Kelly (1998: 16) notes, of 'large-scale quantitative survey of establishments and companies with sophisticated sampling procedures and instrument design and the use of statistical analysis... the Warwick survey of $1977 / 88$... inaugurated a veritable flood of sequels and offshoots'.

In time, however, sociology and institutional analysis would be rejoined. Admittedly some of this dynamic has occurred without reference to mainstream IR in the form of sociological neo-institutionalism (Scott 2001). While this has received some attention in IR (Ackers and Wilkinson 2008) it has, as Jackson and Muellenborn (2012) note, made slow inroads. Rather where sociology finds its voice in contemporary IR institutional analysis is through the integration of concepts like the employment relationship with the institutions that surround this dynamic (Edwards 2003; Ackers 2012). Commentators increasingly stress that national 'IR systems' be sensitive to a broader political sociology which understood IR as embedded in the wider society of different 'national business systems'. Institutions remained central to this because the employment relationship, while holding many consistent and durable features across time and space, was seen to express itself in different institutional configurations, themselves products of history, culture, and political development. Thus Godard (2004: 243) has emphasized the core of IR to be institutional arrangements... which tend to reflect economic, political and social traditions that have become embedded in rules, norms and expectations'. Hyman's (2004: 270) consideration of IR theory, although starting with the capitalist labour process and employment relationship, observes that the institutions of industrial relations must be understood as elements in this apparatus alongside the 'role of ideas, beliefs, social norms and indeed language in shaping industrial relations'. Similarly Ackers $(2005,2012)$ has noted that the employment relationship, while central, can be over-extended into an explanatory meta-narrative. In reality, the employment relationship can only hint at tensions and tendencies:

Once we start asking important questions, such as why are there more strikes in manufacturing than in retail, or more in France than in the UK, the employment relationship per se can tell us little, the labour process not so much more. Instead, we turn to institutions (in their broadest sense) for explanation. And were these 
institutions grown from the seed of an employment relationship? Well, yes, in a certain very generic sense, as with trade unions and employer associations, but they grew on very different soil, in traditional societies that existed before capitalism, and shaped its local development. The employment relationship is a useful ideal type to build IR around, but institutions are the historical forces that pour life into it. (Ackers 2005:540)

The link between institutions and matters of an underlying sociological currency find expression in two avenues associated with contemporaneous IR analysis. The first is in the attempt to reconstitute IR institutionalism under the rubric of 'neo-pluralism'. Initiated by Ackers (2002), neo-pluralism has sought to reconnect institutionalist analysis with traditions of sociological functionalism and the search for social order. This work has sought to move the trajectory of institutional pluralism away from its presumed associations with some strain of conflict theory towards an appreciation of its normative and functionalist heritage. Notably, Durkheim again reappears as the underlying sociological foundations. Although the neo-pluralist architecture deliberately traces its legacy to the Oxford School, the aforementioned thesis of the radical-institutionalists, linking the problem of order at the workplace to wider societal conditions, is perhaps the more natural intellectual antecedent for aspects of this thesis. Ackers (2002: 5), in particular, refers to the 'the wider economic and social dynamics of society' and the need to consider the 'new problem of order' as evident in the destabilizing effects of social discord, rampant individualism, and unregulated market forces on IR and its institutions. The disordering effects of neo-liberalism are seen to pervade the whole of society and then recoil back on to the employment relationship. Where neo-pluralism diverges from the sociological lineage in IR is in its scepticism towards what it perceives as the ahistoricism, and generality of, the employment relationship (Ackers 2012: 5-11). Arguably this scepticism appears ensconced in ideological as much as analytical concerns about the real-world implications of 'Marxian sociology' and a normative preference for Popperian piecemeal social engineering (Ackers and Wilkinson 2008: 65). Many of the neo-pluralist criticisms directed at radical sociology could be reconciled into an empirical and historically institutional method without absence of policy implication (for a classic defence of such method, see Goldthorpe 1977).

In any event the neo-pluralist argument is not incompatible with a second influential strand based around the notion of 'varieties of capitalism' (Soskice 1994; Hopner 2005). While VOC is an updated version of the aforementioned scholarship on corporatism, Wilkinson and Wood (2012) note that interest in the latter had waned as the performance of once successful economies faltered. While the focus on national institutions survived, the focus became less partisan in favouring corporatist economies over more liberalized models. Thus firms in liberal market economies were seen to have greater capacity for innovation, while in coordinated market economies, long-term high trust relations between firms' investors and employees were seen to underpin a strategy of high value added in mature manufacturing. Although this literature has originated from outside the realm of traditional IR, it has been a source of great interest to 
IR scholarship. It has also served to attune the traditional IR analysis to a wider set of influences not directly linked with employment institutions. Central to the VOC analysis is that an interconnected configuration of political, economic, and social arrangements across different levels can combine to produce a range of dynamic effects such as stable and predictable patterns of social relations based on shared understandings and social compromises which lessen the effects of economic uncertainty. The degree of 'fit' between institutional and productive structures, themselves a product of past economic specialization, social traditions, and political choices, is seen to be important.

It is not surprising that the VOC literature has held such appeal to contemporary IR institutionalists trained in the aforementioned classical school of 'Berkeley-Harvard' or 'Oxford'. In many respects the VOC approach partly resonates with the earlier endeavours of the IR institutionalists. Like classical IR, the VOC literature lays emphasis on the integrated and mutually reinforcing character of different system elements. Similarly, institutions are seen to play a central role in creating particularized and regularized patterns. However, unlike Dunlop's system or Clegg's study of collective bargaining, the VOC literature extends beyond the sphere of IR narrowly construed. Thus it is not collective bargaining that has central functionality, but typically the organization of the business system as a whole. Similarly VOC has fallen foul of many of the same criticisms previously levelled by radical critics of institutional IR. The most obvious is the accusation of a revived functionalism, given that much like the Dunlopian approach, actors merely enact the roles required of them by 'the system' (Crouch 2005). Noteworthy too is that the emphasis on 'institutional complementarities' and 'isomorphic processes' in the VOC literature has often been held to downgrade elements of national systems that do not fit the core characteristics of the model. This hearkens back to radical criticisms around classical IR for privileging sources of stability and order rather than conflict and change and the need for considering contradiction and complexity in appropriate frameworks. Both the classical institutional pluralists and the VOC approach, with their emphasis on synergies between institutions, have tended to run shy of such factors. In this regard, it might be said that later theoretical innovations in IR, like the American strategic choice approach, are perhaps superior (Kochan et al. 1986). This at least offers scope for conflictual agency, through the lens of ideology and values, which provides opportunities for managers to actively circumvent and transform institutional pressures to suit their own ends.

Yet despite criticisms of VOC, it has chimed with the radical strain of IR analysis which has sought to embed institutions in 'the wider society'. The adoption of VOC into the IR fold has served to erode the boundary between IR and other fields of analysis, a key goal of the old IR radicals, and situates IR as an integral part of a national business system rather than as distinct sub-system sufficient unto itself as the classical institutional-pluralists sought. Thus, the impact of business financing and corporate governance on IR has been one fruitful outcome of this integration (Gospel and Pendleton 2003). In other ways too, the VOC literature has perhaps reinvigorated the classical institutional ardour to civilize the market order (Flanders 1970). Particularly for IR institutionalists in liberalized settings, there is evidence that alternative types of 
capitalism, more amenable to workers' concerns or which sponsor less conflictual workplaces, have been attractive (Adams 1995). Institutions like German works councils for example have been acknowledged as one reformist vehicle to fashion 'mutual gains' in liberal market economies.

Similarly, while the language of Durkheim is not immediately present in the VOC literature, there is resonance with the aforementioned radical Durkheimian analysis on the need for integration across a number of levels to alleviate anomic mal-integration (Durkheim 1959: 30-1). Specifically, minimizing the three types of anomie which Durkheim held to be predominant in laissez-faire markets required mutually reinforcing initiatives to introduce order into economic life. Although the language is frequently opaque, the task of 'moralizing' economic relationships, even if a principled distribution of rewards could be established, was for Durkheim unlikely to be accomplished unless the economic system as a whole was rationally regulated. Organic solidarity at the workplace was unlikely to occur unless work was perceived to be a purposeful part of the whole, and this was unlikely to occur unless the wider economic system was perceived in some sense as 'rational' and 'ordered'.

There is also a broader alignment with existing IR concerns around the structuring of national employment relations systems and their capacity for generating equitable and socially just outcomes and the Durkheimian thesis on the anomic consequences of the division of labour, laissez-faireism, and the atomistic individualism of liberal market societies. For example, evidence would suggest that workers in Nordic countries have greater job autonomy and discretion than workers in the liberal market economies of the United States, Canada, and Australia. It appears that where national systems are oriented towards rule-governed work, job discretion will be low, whereas those systems oriented to skill-governed work, tend to demonstrate higher levels of autonomy (Dobbin and Boychuk 1999; Gallie 2007). Furthermore, liberal market economies tend, ceteris paribus, to be more vulnerable to severe economic shock and downturn (Reich 2009). Not only do liberal market economies produce more income inequality but they tend to be 'socially dysfunctional' across a number of outcomes in terms of more teenage pregnancies, lower literacy scores, more obesity, worse mental health, more crime and higher proportions of the population incarcerated in prisons (Wilkinson and Pickett 2009). An aside to this is that there is some evidence to suggest that levels of trust between members of the public are lower in countries where income differences are larger (Ulsaner 2002). People trust each other most in what are frequently termed the 'collectivist' Scandinavian countries, while in those termed 'individualist' countries, like the United States, trust is found to be much lower: a trend replicated internally, with trust being lower in those US states where income is more unequally distributed. Echoing Durkheim's (1952: 244) thesis that disorganized economies 'rouse appetites' and excessive acquisitiveness, recent evidence suggests that there are linkages between income disparities and economic crisis: huge gaps in income create perverse incentives that put national economies at risk (Rajan 2010). The source of the global financial crisis of 2008 is an exemplar of this, partly resulting from those at the bottom of the income ladder indulging in cheap credit and home equity loans in order to maintain their 
stagnating living standards, while those at the top with excess surpluses invested in risky mortgage-backed securities and credit derivatives for quick profit. The anomic consequences of this inequality in income, long rumbling beneath the surface, became most plain with the collapse of the mortgage industry but also in the social riots and unrest that have spread across the West in recent years. In this regard, the previous concerns of the Durkheimian imbued IR sociology appear dated in form but not content: 'privatised Keynesianism' (Crouch 2012), itself a product of the neo-liberal organization of employment, rather than striking unions and inflation, has become the new source of disorder.

\section{Conclusion}

Institutions and their impacts have remained central to IR analysis, with many of the more influential accounts on institutional effects being imbued with a broadly functionalist flavour. That is, institutions, and their effects, have been traditionally interpreted in terms of their capacity to generate or maintain 'order' or stability in the employment relationship. Institutions have been viewed as playing a particular role in ensuring interest group exchanges do not break down or descend into conflagration. Of course, institutions were not privileged exclusively because they secured 'order': stability was only of interest to the institutionalist insofar as it preserved what were perceived to be the best features of the democratic polity. In this regard, the institutionalist IR project was a normative device even if it sought to occasionally cloak such influences in the language of sceptical empiricism (cf. Clegg 1975). As such it is difficult to discount the idea that a strong influence in the construction of the institutionalist tradition was opposition to the perceived totalitarianism of communism as much as it was a commitment to liberal or social democracy. Sociologically then, it is no surprise that these scholars sought explanatory tools in the functionalist sociology of Talcott Parsons in the USA and Émile Durkheim in Britain. As interpretative frameworks of industrial society, both sought to understand how interest groups, competing over scarce resources, might be integrated into cohesive social institutions that would avoid the worst excesses of 'disorder'. Yet such discourse became decidedly unfashionable in the academy by the 1970s, as various forms of radical and conflict-orientated social theories emerged, notably in the form of Marxism. At the same time, the Durkheimian associations within IR analysis were not entirely sidelined. The search for 'high trust' workplaces remained evident (Fox 1974), but this was embedded in a broader awareness of the limitations of institutional reform at workplace or even industry level. 'Anomie' at this level was held insurmountable in the face of the wider disordering effects resulting from social inequalities and laissez-faire market societies and their associated possessive individualism. These were structural rather than institutional problems. Although a well-regarded thesis of disorder, it was, however, never entirely of the mainstream. Rather the trajectory of IR analysis in the subsequent years of the monetarist counter-revolution was institutional empiricism, economics, or partial integration into the new field of HRM. Institutions 
at national level, particularly in corporatist arrangements, became a source of interest in seeking out organized responses to stagflationary crisis. Yet institutional IR has over time proven relatively durable. The conceptual importance of the employment relationship and the regulatory institutions that surround this dynamic have been maintained. While in some quarters this has continued to be shaped more by Marx and the materialist labour process (Edwards 2003; Blyton and Turnbull 2004), Durkheimian functionalism has explicitly re-emerged in a strain of neo-pluralism (Ackers 2002). While the former in particular has sought to trace a link back to the Durkheimianism of the Oxford School, by noting the problem of order not just in the workplace, but in the wider relationship between work and society, it is, analytically, if not normatively, closer to the sociological radicalism of Fox, Goldthorpe, and Gilbert. Although long recognized in Durkheimian sociology, and evident in the radical-institutionalist analysis of IR, the link between work and the wider institutional configuration of market societies is now centrally recognized through the influence of the VOC approach. While the VOC literature emerged autonomously from classical IR, there are, as noted, many areas of intellectual similarity. It also points to key lessons for the mainstream institutionalist tradition of IR. In being cognizant of wider societal context, by implication it would suggest that the inherent reformist inclinations of the institutionalist tradition must be willing to consider, in the words of Fox (1985a: 171), a wider 'assault on gross inequalities of wealth, income and privilege' if the contemporary disorder afflicting many contemporary liberalized market societies is to be adequately addressed.

\section{ACKNOWLEDGEMENT}

I would like to thank the editors for helpful comments and guidelines on an earlier draft of this chapter.

\section{REFERENCES}

Ackers, P. (2002). 'Reframing Employment Relations: The Case for Neo-Pluralism', Industrial Relations Journal, 33(1): 2-19.

- (2005). 'Theorizing the Employment Relationship: Materialists and Institutionalists', British Journal of Industrial Relations, 43(3): 537-42.

_ (2011). 'The Changing System of British Industrial Relations, 1954-1979: Hugh Clegg and the Warwick Sociological Turn', British Journal of Industrial Relations, 49(2):306-30.

— (2012). 'Rethinking the Employment Relationship: Neo-Pluralist Critique of British Industrial Relations Orthodoxy', International Journal of Human Resource Management, iFirst: $1-18$.

Ackers, P. and Wilkinson, A. (2008). 'Industrial Relations and the Social Sciences', in P. Blyton, N. Bacon, J. Fiorito, and E. Heery (eds.), The Sage Handbook of Industrial Relations. London: Sage, 53-69. 
Adams, R. J. (1995). Industrial Relations Under Liberal Democracy: North America in Comparative Perspective. Columbia, SC: University of South Carolina Press.

Aldridge, A. (1976). Power, Authority and Restrictive Practices. Oxford: Blackwell.

Allen, V. I. (1971). The Sociology of Industrial Relations. London: Longman.

Armstrong, P., Glyn, A., and Harrison, J. (1984). Capitalism Since World War II: The Making and Breakup of the Great Boom. London: Fontana.

Blyton, P. and Turnbull, P. (2004). The Dynamics of Employee Relations. Basingstoke: Palgrave Macmillan.

Braverman, H. (1974). Labor and Monopoly Capital: The Degradation of Work in the Twentieth Century. New York: Monthly Review Press.

Clegg, H. A. (1960). A New Approach to Industrial Democracy. Oxford: Blackwell.

- (1975). 'Pluralism in Industrial Relations', British Journal of Industrial Relations, 13(1):309-16.

- (1976). Trade Unionism Under Collective Bargaining. Oxford: Blackwell.

- (1979). The Changing System of Industrial Relations in Great Britain. Oxford: Blackwell.

Coates, D. (ed.) (2005). Varieties of Capitalism, Varieties of Approach. Basingstoke: Palgrave Macmillan.

Commons, J. R. (1950). The Economics of Collective Action. New York: Macmillan.

Crouch, C. (2005). 'Models of Capitalism', New Political Economy, 10(4): 441-56.

- (2012). 'Beyond the Flexibility/Security Trade Off: Reconciling Confident Consumers with Insecure Workers', British Journal of Industrial Relations, 50(1): 1-22.

Dahl, R. (1958). 'A Critique of the Ruling Elite Model', American Political Science Review, 52(2): 463-9.

Dahrendorf, R. (1959). Class and Class Conflict. London: Routledge \& Kegan Paul.

Dobbin, F. and Boychuk, T. (1999). 'National Employment Systems and Job Autonomy: Why Job Autonomy is High in the Nordic Countries and Low in the United States, Canada and Australia, Organization Studies, 20(2): 257-91.

Domhoff, G. W. (1967). Who Rules America? Englewood Cliffs, NJ: Prentice Hall.

Dunlop, J. T. (1958). Industrial Relations Systems. New York: Henry Holt and Co.

Durkheim, E. (1952). Suicide. London: Routledge.

- (1959). Socialism. London: Routledge.

- (1982). The Rules of Sociological Method. New York: Free Press.

- (1984). The Division of Labour in Society. New York: Free Press.

Edwards, P. K. (2003). 'The Employment Relationship and the Field of Industrial Relations', in Edwards (ed.), Industrial Relations: Theory \& Practice. Oxford: Blackwell, 1-36.

Edwards, P. K. and Scullion, H. (1982). The Social Organization of Industrial Conflict: Control and Resistance in the Workplace. Oxford: Blackwell.

Flanders, A. (1964). The Fawley Productivity Agreements. London: Faber.

- (1970). Management and Unions. London: Faber.

Flanders, A. and Clegg, H. A. (eds.) (1954). The System of Industrial Relations in Great Britain. Oxford: Blackwell.

Fox, A. (1971). A Sociology of Work in Industry. London: Collier-Macmillan.

— (1973). 'Industrial Relations: A Social Critique of Pluralist Ideology', in J. Child (ed.), Man and Organization. London: George Allen \& Unwin, 185-233.

- (1974). Beyond Contract: Work, Power and Trust Relations. London: Faber and Faber.

- (1985a). Man Mismanagement. London: Hutchinson.

- (1985b). History and Heritage. London: George Allen \& Unwin. 
Fox, A. and Flanders, A. (1969). 'The Reform of Collective Bargaining: From Durkheim to Donovan', British Journal of Industrial Relations, 7(2): 151-80.

Frege, C. M. and Kelly, J. (eds.) (2004). Varieties of Unionism: Strategies for Union Revitalization in a Globalizing Economy. Oxford: Oxford University Press.

Gallie, D. (2007). 'Welfare Regimes, Employment Systems and Job Preference Orientations', European Sociological Review, 23(3): 279-93.

Giddens, A. (1984). The Constitution of Society. Cambridge: Polity Press.

Gilbert, M. (1978). 'Neo-Durkheimian Analyses of Economic Life and Strife: From Durkheim to the Social Contract', Sociological Review, 26: 729-54.

- (1986). Inflation and Social Conflict, Sussex: Wheatsheaf Books.

Glyn, A. and Sutcliffe, R. B. (1972). British Capitalism, Workers and the Profit Squeeze. London: Penguin.

Godard, J. (1994). 'Beyond Empiricism: Towards a Reconstruction of IR Theory and Research', Advances in Industrial and Labor Relations, 6(1): 1-35.

- (2004). 'The New Institutionalism, Capitalist Diversity and Industrial Relations', in B. E. Kaufman (ed.) Theoretical Perspectives on Work and the Employment Relationship. Ithaca: Cornell University Press, 229-64.

Goldthorpe, J. H. (1969). 'Social Inequality and Social Integration in Modern Britain', Advancement of Science, 26: 190-202.

— (1975). 'Book Reviews: Beyond Contract', British Journal of Industrial Relations, 13(1):135-48.

- (1977). 'Industrial Relations in Great Britain: A Critique of Reformism', in T. Clarke and L. Clements (eds.), Trade Unions Under Capitalism. London: Fontana, 184-224.

— (1978). 'The Current Inflation: Towards a Sociological Account', in F. Hirsch and J. H. Goldthorpe (eds.), The Political Economy of Inflation. London: Martin Robertson, 186-214.

- (1984). 'The End of Convergence: Corporatist and Dualist Tendencies in Modern Western Societies', in Goldthorpe (ed.), Order and Conflict in Contemporary Capitalism. Oxford: Clarendon Press, 315-43.

Goldthorpe,J.H., Lockwood, D., Bechhofer, F., and Platt,J.(1968). The Affluent Worker:Industrial Attitudes and Behaviour. Cambridge: Cambridge University Press.

Gospel, H. and Pendleton, A. (2003). 'Finance, Corporate Governance and the Management of Labour: A Conceptual and Comparative Analysis', British Journal of Industrial Relations, 41(3): 557-82.

Gouldner, A. W. (1971). The Coming Crisis of Western Sociology. London: Heinemann.

Heery, E. (2008). 'System and Change in Industrial Relations Analysis', in P. Blyton, N. Bacon, J. Fiorito, and Heery (eds.), The Sage Handbook of Industrial Relations. London: Sage, 69-91.

Herding, R. (1972). Job Control and Union Structure. Rotterdam: Rotterdam University Press.

Hopner, M. (2005). 'What Connects Industrial Relations and Corporate Governance? Explaining Institutional Complementarity', Socio-Economic Review, 3(2): 331-58.

Howell, C. (2003). 'Varieties of Capitalism: And Then There Was One?', Comparative Politics, 36(1): 103-24.

Hyman, R. (1975). Industrial Relations: A Marxist Introduction. London: Macmillan.

- (2004). 'Is Industrial Relations Theory Always Ethnocentric?', in B. E. Kaufman (ed.), Theoretical Perspectives on Work and the Employment Relationship. Ithaca: Cornell University Press, 265-92.

Jackson, G. and Muellenborn, T. (2012). 'Understanding the Role of Institutions in Industrial Relations: Perspectives from Classical Sociological Theory', Industrial Relations, 51(1): 472-500. 
Kaufman, B. (2004). The Global Evolution of Industrial Relations. Geneva: ILO.

Kelly, J. (1998). Rethinking Industrial Relations: Mobilization, Collectivism and Long Waves. London: Routledge.

- (2010). Ethical Socialism and the Trade Unions: Allan Flanders and British Industrial Relations Reform. London: Routledge.

Kerr, C. (1964). 'Industrial Relations and the Liberal Pluralist', in C. Kerr (ed.), Labour and Management in Industrial Society. New York: Anchor, 8-14.

Kerr, C., Dunlop, J. T., Harbison, F. H., and Myers, C. A. (1973). Industrialism and Industrial Man. London: Penguin.

Kochan, T. A., Katz, H. C., and McKersie, R. (1986). The Transformation of American Industrial Relations. New York: Basic Books.

Lockwood, D. (1993). Solidarity and Schism: The Problem of Disorder in Durkheimian and Marxist Sociology. Oxford: Oxford University Press.

Martin, R. (1999). 'Mobilization Theory: A New Paradigm for Industrial Relations', Human Relations, 52(9): 1205-16.

Nichols, T. and Beynon, H. (1977). Living With Capitalism: Class Relations and the Modern Factory. London: Routledge \& Kegan Paul.

Parsons, T. (1951). The Social System. Chicago: Free Press.

- (1968). The Structure of Social Action, Volume II. Chicago: Free Press.

Perlman, S. (1928). A Theory of the Labor Movement. Philadelphia: Porcupine.

Poole, M. (1981). Theories of Trade Unionism: A Sociology of Industrial Relations. London: Routledge \& Kegan Paul.

Rajan, R. (2010). Fault Lines: How Hidden Fractures Still Threaten the World Economy. Princeton: Princeton University Press.

Reich, M. (2009). 'The Current Crisis of Capitalism: Insights from Social Structure of Accumulation Theory', paper presented to the Annual Meeting of SASE Conference, Paris, July.

Schmitter, P. C. (1974). 'Still the Century of Corporatism?', Review of Politics, 36(1): 85-131.

Scott, W. R. (2001). Institutions and Organizations. Thousand Oaks, CA: Sage.

Soskice, D. (1994). 'Reconciling Markets and Institutions: The German Apprenticeship System', in L. Lynch (ed.), Training and the Private Sector: International Comparisons. Chicago: University of Chicago Press, NBER Conference Volume, 25-60.

Terry, M. and Edwards, P. K. (1988). Shopfloor Politics and Job Controls: The Post-War Engineering Industry. Oxford: Blackwell.

Thompson, P. (1983). The Nature of Work: An Introduction to Debates on the Labour Process. Basingstoke: Macmillan.

Ulsaner, E. M. (2002). The Moral Foundations of Trust. Cambridge: Cambridge University Press.

Webb, S. and Webb, B. (1920). Industrial Democracy. London: Longman.

Wilkinson, R. and Pickett, K. (2009). The Spirit Level: Why Equality is Better for Everyone. London: Penguin.

Wilkinson, A. and Wood, G. (2012). 'Institutions and Employment Relations: The State of the Art', Industrial Relations, 51(1): 373-88.

Wood, S. (2000). 'The BJIR and Industrial Relations in the New Millennium', British Journal of Industrial Relations, 38(1): 1-5. 